\title{
Molecular identification of Helicobacter DNA in human gastric adenocarcinoma tissues using Helicobacter species-specific 16S rRNA PCR amplification and pyrosequencing analysis
}

\author{
HYE SEUNG HAN ${ }^{1,3}$, KYUNG-YUNG LEE ${ }^{2}$, SO DUG LIM ${ }^{1}$, WAN SEOP KIM ${ }^{1}$ and TAE SOOK HWANG ${ }^{1}$ \\ Departments of ${ }^{1}$ Pathology, ${ }^{2}$ Surgery, and ${ }^{3}$ Research Institute of Medical Science, \\ Konkuk University School of Medicine, Seoul 143-729, Korea
}

Received September 14, 2009; Accepted March 10, 2010

DOI: 10.3892/ol_00000098

\begin{abstract}
Helicobacter pylori (H. pylori) is a microaerophilic gram-negative bacterium known to be associated with chronic gastritis, peptic ulcer and gastric adenocarcinoma. In the present study, the presence of Helicobacter DNA was investigated using a Helicobacter species-specific 16S rRNA PCR amplification and pyrosequencing analysis in 51 resected gastric adenocarcinomas. DNA was extracted from paraffinembedded tissues of resected gastric adenocarcinomas. PCR primers were designed to amplify the 133-bp PCR fragment in highly conserved regions of the $16 \mathrm{~S}$ rRNA gene. The sequence of the PCR products was analyzed using a PSQ 96 system with SQA software. The pyrosequencing analysis of 16S rRNA showed that $H$. pylori was present in $47(92.2 \%)$ of the 51 gastric adenocarcinomas. In the $4 \mathrm{H}$. pylori-negative cases, Helicobacter cinaedi (2 cases), Helicobacter mustelae (1 case) and Campylobacter hyointestinalis (1 case) were detected. Pyrosequencing technology was useful in the identification and differentiation of $H$. pylori from other species by analyzing the gene encoding 16S rRNA. Gastric adenocarcinoma tissues contain bacteria, and the majority are H. pylori. Helicobacter cinaedi, Helicobacter mustelae and Campylobacter hyointestinalis rarely occur. The roles of these organisms in the pathogenesis of gastric adenocarcinoma remain unclear.
\end{abstract}

\section{Introduction}

Helicobacter pylori (H. pylori) is a microaerophilic gramnegative bacterium known to be associated with chronic gastritis, peptic ulcer and gastric adenocarcinoma (1). It is of

Correspondence to: Dr Tae Sook Hwang, Department of Pathology, Konkuk University Hospital, 4-12 Hwayang-dong, Gwangjin-gu, Seoul 143-729, Korea

E-mail: tshwang@kuh.ac.kr

Key words: Helicobacter, gastric adenocarcinoma, 16S rRNA, pyrosequencing great clinical importance to identify the organism in gastric specimens. Subsequently, several diagnostic assays exist. $H$. pylori infection in gastric specimens can be demonstrated through the use of culture, histological examination of biopsy specimens using different stains, assaying for urease activity and PCR assay with the aim of specifically detecting $H$. pylori DNA (2). Assays based on the use of PCR to detect the presence of $H$. pylori DNA using several different gene targets have been described (2-10). Moreover, it is well known that the PCR assay is highly reliable in the detection of $H$. pylori. The pyrosequencing analysis was employed to identify $H$. pylori by sequencing a part of the $16 \mathrm{~S}$ rRNA gene covering the $H$. pylori signature sequence (6). The $H$. pylori signature sequence allows for the distinction of the organism from a set of other bacterial species (11). This study investigated the possibility of using pyrosequencing technology to verify the species identity of $H$. pylori from paraffin-embedded tissues of resected gastric adenocarcinomas by amplifying a part of the 16S rRNA gene using broadly reactive primers followed by the sequencing of a $20-b p$ sequence unique to the $16 \mathrm{~S}$ rRNA gene of $H$. pylori.

\section{Materials and methods}

DNA extraction. DNA was extracted from paraffin sections of 51 resected gastric adenocarcinomas including 21 intestinal, 24 diffuse and 6 mixed types. Briefly, 50-100 $\mu$ l of DNA extraction buffer solution [50 mM Tris buffer ( $\mathrm{pH} 8.3), 1 \mathrm{mM}$ EDTA (pH 8.0), 5\% Tween-20 and $100 \mu \mathrm{g} / \mathrm{ml}$ proteinase $\mathrm{K}$ ] with $10 \%$ resin was added to scraped tissue and incubated at $56^{\circ} \mathrm{C}$ for a minimum of $1 \mathrm{~h}$. Following incubation, the tubes were heated at $100^{\circ} \mathrm{C}$ for $10 \mathrm{~min}$. Tubes were centrifuged to pellet the debris, and $5 \mu \mathrm{l}$ of the supernatant was used in the PCR reaction.

PCR amplification for Helicobacter pylori identification. To identify $H$. pylori the primers used were: forward, 5'-biotin-AGGGGTAAAATCCGTAGAGAT-3' and reverse, 5'-CGTTTAGGGCGTGGACTA-3'. The latter primer amplifies a 133-bp DNA fragment from the ' $16 \mathrm{~S}$ rRNA' region of $H$. pylori. Briefly, $5 \mu \mathrm{l}$ of DNA was added to reach $50 \mu \mathrm{l}$ of PCR solution mix, containing $0.2 \mathrm{mmol}$ each of dNTP, 
$1.5 \mathrm{mmol} / 1 \mathrm{MgCl}_{2}$, 1X PCR buffer, 1.5 units of Immolase DNA Taq polymerase (Bioline, London, UK) and 20 pmol of each primer. PCR was performed for $5 \mathrm{~min}$ at $95^{\circ} \mathrm{C}, 50$ cycles (30 sec at $95^{\circ} \mathrm{C}, 30 \mathrm{sec}$ at $52^{\circ} \mathrm{C}$ and $30 \mathrm{sec}$ at $72^{\circ} \mathrm{C}$ ) and 10 min at $72^{\circ} \mathrm{C}$ using a PTC-220 thermal cycler (Bio-Rad, USA). The PCR products were electrophoresed in an agarose gel to confirm successful amplification of the PCR product.

Pyrosequencing analysis for Helicobacter pylori identification. Biotinylated PCR products were immobilized to streptavidin-coated beads (Amersham Pharmacia Biotech AB, Sweden) using solution from the $\mathrm{PSQ}^{\mathrm{TM}} 96$ Sample Preparation kit (Pyrosequencing AB, UK), following a standard protocol. Beads $(10 \mu \mathrm{l})$ were diluted in binding buffer with biotinylated PCR products and incubated for $10 \mathrm{~min}$ at room temperature. The beads were transferred to a filter probe, and liquid was removed by vacuum filtration. DNA was separated in denaturation solution for $2 \mathrm{~min}$. The templates were washed with washing buffer, transferred to a PSQ 96 SQA plate and annealed with the sequencing primer, reverse, 5'-CTCCCCA CGCTTT-3' in annealing buffer at room temperature. Samples were analyzed using the PyroMark ID system (Biotage, UK) with SQA software and the SQA reagent kit (Biotage) for sequence analysis.

\section{Results}

DNA was extracted from the paraffin-embedded tissues of 51 resected gastric adenocarcinomas. PCR primers were designed to amplify the 133-bp PCR fragment in highly conserved regions of the $16 \mathrm{~S}$ rRNA gene. The sequence of the PCR products was analyzed using the PyroMark ID system with SQA software and the SQA reagent kit. Sequence analysis for the identification of $H$. pylori by sequencing a section of the $16 \mathrm{~S}$ rRNA gene covering the $H$. pylori signature sequence was carried out. Fig. 1 shows the representative results from the analysis of the paraffinembedded tissues of 51 resected gastric adenocarcinomas. Pyrosequencing analysis of 16S rRNA showed that $H$. pylori was present in $47(92.2 \%)$ of the 51 gastric adenocarcinomas: 18 of the 21 intestinal-, 23 of the 24 diffuse- and all of the 6 mixed-type. In the $4 H$. pylori-negative cases, Helicobacter cinaedi (H. cinaedi) (2 cases), Helicobacter mustelae (H. mustelae) (1 case) and Campylobacter hyointestinalis ( $C$. hyointestinalis) (1 case) were detected. Two $H$. cinaedi-and $1 C$. hyointestinalis-positive cases were detected in the intestinal-type, and $1 \mathrm{H}$. mustelae case was detected in the diffuse-type adenocarcinomas.

\section{Discussion}

A variety of diagnostic procedures are used to identify $H$. pylori in clinical samples. No single test is optimal due to the length of time required to perform the test, lack of sensitivity or irreproducibility (5). Culture and histological examination of biopsy specimens using different stains and assaying for urease activity have the disadvantages of lack of sensitivity and long incubation periods. Assays based on the use of PCR to detect the presence of $H$. pylori DNA using several different gene targets showed that PCR is feasibile for the rapid, sensitive and specific detection of $H$. pylori (2-5,7-10,12). Using the PyroMark ID system with SQA software and the SQA reagent kit to amplify a section of the $16 \mathrm{~S}$ rRNA gene it was possible to analyze bacterial genetic targets in DNA extracted directly from human gastric tissues without the prolonged culturing of bacteria. Subsequently, the organism was differentiated from a set of other bacterial species (6).

H. pylori has been classified as a Group I carcinogen. Previous epidermiologic studies established a strong causal relationship between $H$. pylori infection and gastric cancer (13-16). A nationwide survey conducted in South Korea in 1998 on the serologic prevalence of $H$. pylori infection concluded that the prevalence of $H$. pylori was $66.9 \%$ among adults ( $\geq 16$ years), a percentage that decreased to $59.6 \%$ in 2005 (17). In this study, H. pylori was present in 47 (92.2\%) of 51 gastric adenocarcinoma tissues from Korean patients. Persistent infection of the gastric mucosa by $H$. pylori initiates an inflammatory cascade that progresses into atrophic gastritis, a condition associated with a reduced capacity for the secretion of gastric acid and an increased risk of developing gastric cancer (18).

Two cases of $H$. cinaedi infection, 1 case of $C$. hyointestinalis infection and 1 case of $H$. mustelae infection in the $4 H$. pylori-negative cases were noted in the present study. Two $H$. cinaedi- and $1 C$. hyointestinalis-positive cases were detected in the intestinal-type and $1 \mathrm{H}$. mustelae in the diffuse-type adenocarcinomas. Molecular evidence of $H$. cinaedi organisms in 2 of 126 urease-negative human gastric biopsy specimens was previously reported (19). H. cinaedi was found to cause gastroenteritis (20) and extraintestinal infection, particularly in immunocompromised patients (21). C. hyointestinalis was initially described by Gebhart et $a l$ as a possible cause of porcine proliferative enteritis (22). The organism has subsequently been isolated from the feces of humans with gastroenteritis and, in a few cases, from the blood of patients with bacteremia (23). Although $H$. cinaedi and $C$. hyointestinalis were previously associated with gastroenteritis, the incidence and roles of these organisms in gastric carcinogenesis remain unclear. H. mustelae is a gastric pathogen that has many biochemical, molecular and phenotypic characteristics similar to those of $H$. pylori (24). H. mustelae infection was found to increase gastric epithelial proliferation, as noted in $H$. pylori-infected humans, presumably due to a chronic inflammatory response (25). A previous study suggested that the high tumor incidence reported in MNNG-treated ferrets reflected the involvement of $H$. mustelae infection in the carcinogenic process in these animals (26). A previously reported case linking $H$. mustelae and gastric adenocarcinoma supports the hypothesis that $H$. mustelae, similar to $H$. pylori in humans, may be a gastric co-carcinogen in ferrets (27). However, this hypothesis has yet to be confirmed in humans.

Pyrosequencing technology is useful in the identification and differentiation of $H$. pylori from other species by analyzing the gene encoding $16 \mathrm{~S}$ rRNA. Gastric adenocarcinoma tissues contain bacteria and the majority are $H$. pylori. $H$. cinaedi, H. mustelae and $C$. hyointestinalis rarely occur. The roles of these organisms in the pathogenesis of gastric adenocarcinoma remain unclear. 
A Quality: Good
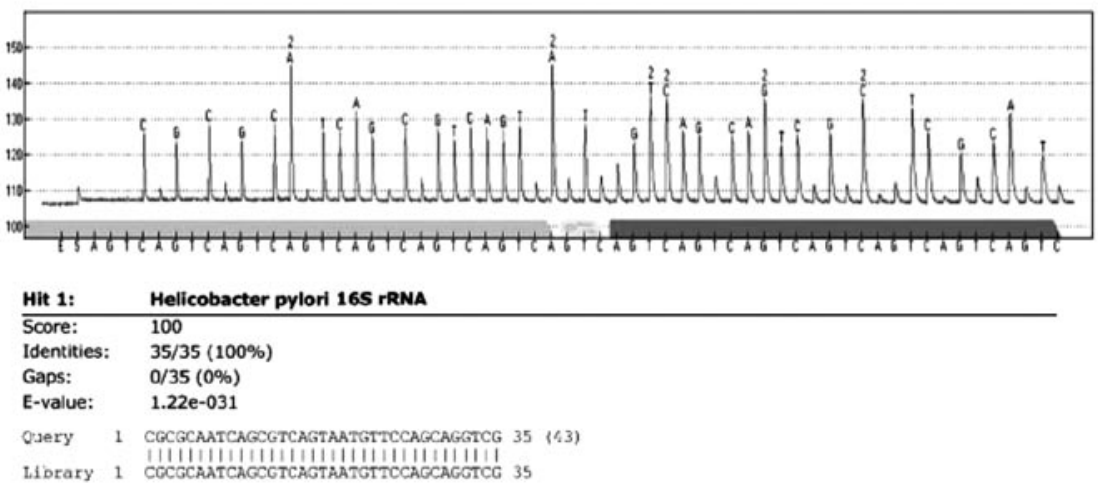

B

Result: Helicobacter cinaedi CCUG 19218.

Quality: $\quad 25715$

I. Information: Top result contains multiple hits (2).
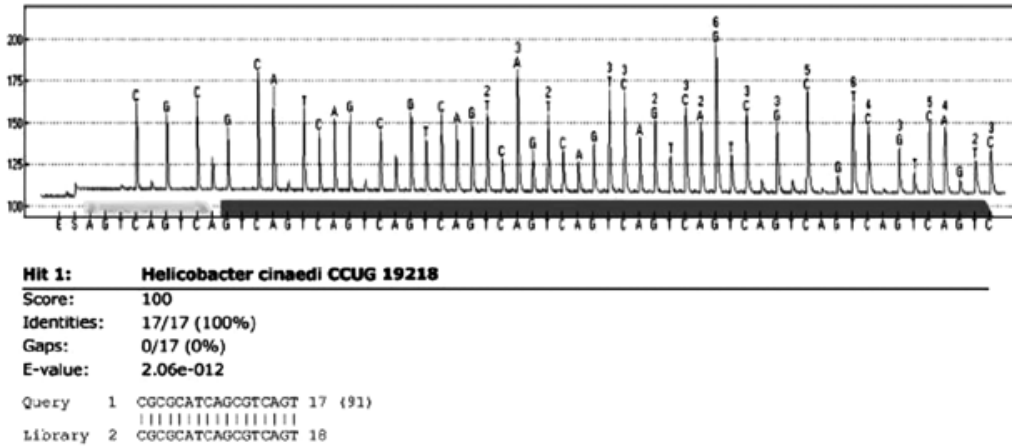

C

$\begin{array}{lll}\text { Result: } & \text { Campylobacter hyointestinalis CCUG } 14169 & \text { Score: } 100 \\ \text { Quality: } & \text { Good }\end{array}$
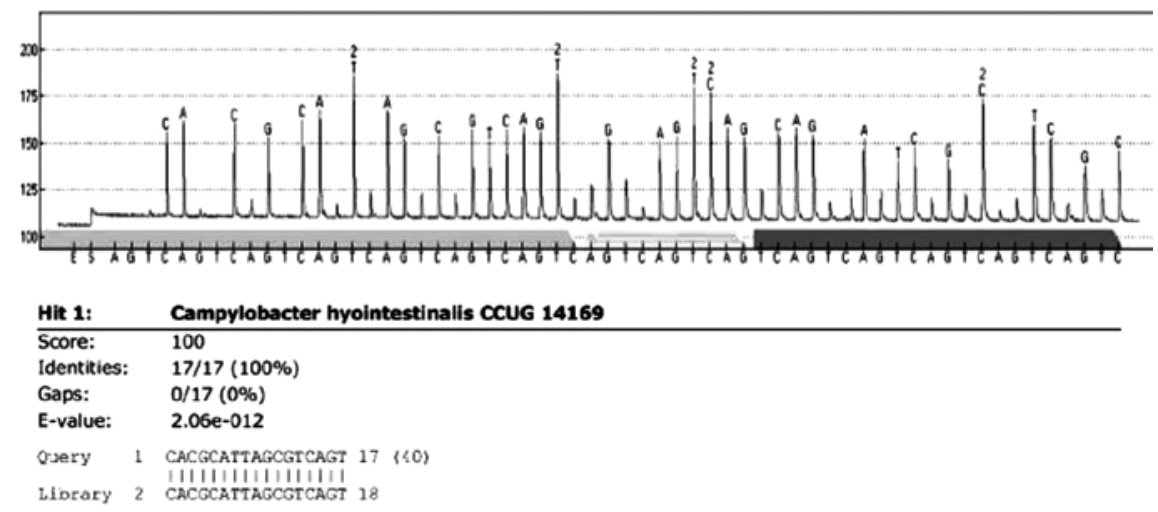

D

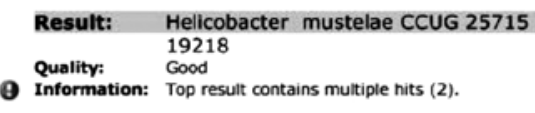

Figure 1. Sequence analysis using the PyroMark ID system with SQA software and the SQA reagent kit. Sequence analyses of the 16S rRNA gene of (A) H. pylori, (B) H. cinaedi, (C) C. hyointestinalis and (D) H. mustelae. 


\section{Acknowledgements}

This study was supported by Konkuk University.

\section{References}

1. Blaser MJ and Parsonnet J: Parasitism by the 'slow' bacterium Helicobacter pylori leads to altered gastric homeostasis and neoplasia. J Clin Invest 94: 4-8, 1994.

2. Weiss J, Mecca J, da Silva E and Gassner D: Comparison of PCR and other diagnostic techniques for detection of Helicobacter pylori infection in dyspeptic patients. J Clin Microbiol 32: 1663-1668, 1994.

3. Clayton CL, Kleanthous H, Coates PJ, Morgan DD and Tabaqchali S: Sensitive detection of Helicobacter pylori by using polymerase chain reaction. J Clin Microbiol 30: 192-200, 1992.

4. Engstrand L, Nguyen AM, Graham DY and el-Zaatari FA: Reverse transcription and polymerase chain reaction amplification of rRNA for detection of Helicobacter species. J Clin Microbiol 30: 2295-2301, 1992.

5. Hammar M, Tyszkiewicz T, Wadstrom T and O'Toole PW: Rapid detection of Helicobacter pylori in gastric biopsy material by polymerase chain reaction. J Clin Microbiol 30: 54-58, 1992.

6. Hjalmarsson S, Alderborn A, Fock C, Muldin I, Kling H, Uhlen $M$ and Engstrand L: Rapid combined characterization of microorganism and host genotypes using a single technology. Helicobacter 9: 138-145, 2004.

7. Hoshina S, Kahn SM, Jiang W, et al: Direct detection and amplification of Helicobacter pylori ribosomal $16 \mathrm{~S}$ gene segments from gastric endoscopic biopsies. Diagn Microbiol Infect Dis 13 473-479, 1990

8. Valentine JL, Arthur RR, Mobley HL and Dick JD: Detection of Helicobacter pylori by using the polymerase chain reaction. $\mathrm{J}$ Clin Microbiol 29: 689-695, 1991.

9. Van Zwet AA, Thijs JC, Kooistra-Smid AM, Schirm J and Snijder JA: Sensitivity of culture compared with that of polymerase chain reaction for detection of Helicobacter pylori from antral biopsy samples. J Clin Microbiol 31: 1918-1920, 1993.

10. Wang JT, Lin JT, Sheu JC, Yang JC, Chen DS and Wang TH: Detection of Helicobacter pylori in gastric biopsy tissue by polymerase chain reaction. Eur J Clin Microbiol Infect Dis 12: 367-371, 1993.

11. Eckloff BW, Podzorski RP, Kline BC and Cockerill FR III: A comparison of $16 \mathrm{~S}$ ribosomal DNA sequences from five isolates of Helicobacter pylori. Int J Syst Bacteriol 44: 320-323, 1994.

12. Ho SA, Hoyle JA, Lewis FA, et al: Direct polymerase chain reaction test for detection of Helicobacter pylori in humans and animals. J Clin Microbiol 29: 2543-2549, 1991.

13. El-Omar EM, Oien K, Murray LS, et al: Increased prevalence of precancerous changes in relatives of gastric cancer patients: critical role of H. pylori. Gastroenterology 118: 22-30, 2000.
14. Eslick GD, Lim LL, Byles JE, Xia HH and Talley NJ: Association of Helicobacter pylori infection with gastric carcinoma: a metaanalysis. Am J Gastroenterol 94: 2373-2379, 1999.

15. Limburg P, Qiao Y, Mark S, et al: Helicobacter pylori seropositivity and subsite-specific gastric cancer risks in Linxian, China. J Natl Cancer Inst 93: 226-233, 2001.

16. Uemura N, Okamoto S, Yamamoto S, et al: Helicobacter pylori infection and the development of gastric cancer. N Engl J Med 345: 784-789, 2001.

17. Kim N, Park RY, Cho SI, et al: Helicobacter pylori infection and development of gastric cancer in Korea: long-term follow-up. J Clin Gastroenterol 42: 448-454, 2008.

18. Dicksved J, Lindberg M, Rosenquist M, Enroth H, Jansson JK and Engstrand L: Molecular characterization of the stomach microbiota in patients with gastric cancer and in controls. J Med Microbiol 58: 509-516, 2009.

19. Pena JA, McNeil K, Fox JG and Versalovic J: Molecular evidence of Helicobacter cinaedi organisms in human gastric biopsy specimens. J Clin Microbiol 40: 1511-1513, 2002.

20. Quinn TC, Goodell SE, Fennell C, Wang SP, Schuffler MD, Holmes KK and Stamm WE: Infections with Campylobacter jejuni and Campylobacter-like organisms in homosexual men. Ann Intern Med 101: 187-192, 1984.

21. Burman WJ, Cohn DL, Reves RR and Wilson ML: Multifocal cellulitis and monoarticular arthritis as manifestations of Helicobacter cinaedi bacteremia. Clin Infect Dis 20: 564-570, 1995.

22. Gebhart CJ, Ward GE, Chang K and Kurtz HJ: Campylobacter hyointestinalis (new species) isolated from swine with lesions of proliferative enteritis. Am J Vet Res 44: 361-367, 1983.

23. Lastovica AJ: Campylobacter/Helicobacter bacteremia in Cape Town, South Africa, 1977-1995. In: Campylobacters, Helicobacters and Related Organisms. Newell DG, Ketley JM and Feldman RA (eds). Plenum Press, New York, pp475-479, 1996.

24. Fox JG, Edrise BM, Cabot EB, Beaucage C, Murphy JC and Prostak KS: Campylobacter-like organisms isolated from gastric mucosa of ferrets. Am J Vet Res 47: 236-239, 1986.

25. Yu J, Russell RM, Salomon RN, Murphy JC, Palley LS and Fox JG: Effect of Helicobacter mustelae infection on ferret gastric epithelial cell proliferation. Carcinogenesis 16: 1927-1931, 1995.

26. Fox JG, Correa P, Taylor NS, Lee A, Otto G, Murphy JC and Rose R: Helicobacter mustelae associated gastritis in ferrets: an animal model of Helicobacter pylori gastritis in humans. Gastroenterology 99: 352-361, 1990.

27. Fox JG, Dangler CA, Sager W, Borkowski R and Gliatto JM: Helicobacter mustelae-associated gastric adenocarcinoma in ferrets (Mustela putorius furo). Vet Pathol 34: 225-229, 1997. 